\title{
Nuclear Transit and HIV LTR Binding of NF- $\kappa B$ Subunits Held by I $\kappa B$ Proteins: Implications for HIV-1 Activation
}

\author{
Sohrab Z. Khan ${ }^{1,+}$, Sofia Gasperino ${ }^{1}$ and Steven L. Zeichner ${ }^{1,2, *}$ \\ 1 Department of Pediatrics, Child Health Research Center, and the Pendleton Pediatric Infectious Disease \\ Laboratory, University of Virginia, Charlottesville, VA 22908, USA; sohrabzafar@gmail.com (S.Z.K.); \\ SLG7S@hscmail.mcc.virginia.edu (S.G.) \\ 2 Department of Microbiology, Immunology, and Cancer Biology, University of Virginia, \\ Charlottesville, VA 22908, USA \\ * Correspondence: Zeichner@virginia.edu \\ + Current address: Sarepta Therapeutics Inc, Dublin, OH 43210, USA.
}

Received: 13 May 2019; Accepted: 11 December 2019; Published: 16 December 2019

\begin{abstract}
No effective therapy to eliminate the HIV latently infected cell reservoir has been developed. One approach, "shock and kill", employs agents that activate HIV, subsequently killing the activated infected cells and/or virus. Shock and kill requires agents that safely and effectively activate HIV. One class of activation agents works through classical NF- $\kappa \mathrm{B}$ pathways, but global NF- $\kappa \mathrm{B}$ activators are non-specific and toxic. There exist two major $\mathrm{I}_{\kappa} \mathrm{Bs}$ : $\mathrm{I} \kappa \mathrm{B} \alpha$, and $\mathrm{I} \kappa \mathrm{B} \varepsilon$, which hold activating $\mathrm{NF}-\kappa \mathrm{B}$ subunits in the cytoplasm, releasing them for nuclear transit upon cell stimulation. IкB $\alpha$ was considered the main I $\kappa B$ responsible for gene expression regulation, including HIV activation. $\mathrm{I} \kappa \mathrm{B} \varepsilon$ is expressed in cells constituting much of the latent HIV reservoir, and $\mathrm{I} \kappa \mathrm{B} \varepsilon$ knockout mice have a minimal phenotype, suggesting that $\mathrm{I} \kappa \mathrm{B} \varepsilon$ could be a valuable target for HIV activation and reservoir depletion. We previously showed that targeting $\mathrm{I} \kappa \mathrm{B} \varepsilon$ yields substantial increases in HIV

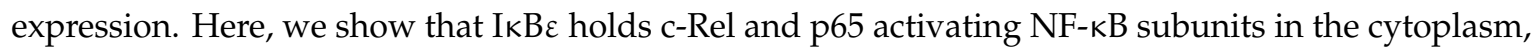
and that targeting $\mathrm{I} \kappa \mathrm{B} \varepsilon$ with siRNA produces a strong increase in HIV expression associated with enhanced c-Rel and p65 transit to the nucleus and binding to the HIV LTR of the activating NF- $\kappa$ Bs, demonstrating a mechanism through which targeting $\mathrm{I} \kappa \mathrm{B} \varepsilon$ increases HIV expression. The findings suggest that it may be helpful to develop HIV activation approaches, acting specifically to target IKB $\varepsilon$ and its interactions with the NF-kBs.
\end{abstract}

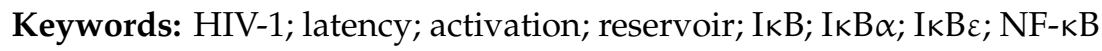

\section{Introduction}

While combination antiretroviral therapy (cART) can effectively control disease in a patient infected with HIV-1, cART does not cure a patient of the infection, due to the existence of a persistent reservoir of long-lived latently infected cells, largely CD4+ memory T cells (recently reviewed in [1-4]). Considerable interest has centered on developing ways to attack, deplete, and ideally eliminate the long-lived reservoir of latently infected cells. One possible approach to attacking the latent reservoir has been termed "shock and kill" (reviewed in [5]), in which a patient would be treated with agents that activate latent HIV, then given antiviral or immunologic therapies that would destroy the resulting activated viruses and their host cells.

Much work has been done to develop effective HIV activators or latency-reversing agents (LRAs) — the "shock" component of "shock and kill." Shock and kill strategies are theoretically appealing, but unfortunately have generally proved ineffective in clinical settings, and in some cases 
have been shown to be highly toxic. Available LRAs also lack cell specificity and their broad mechanism of action yields toxicity, off-target effects, and limited dosing range [6]. While blocks to HIV activation occur at several different levels, transcriptional initiation is one key level; and adequate transcriptional initiation must be present for other levels, such as transcriptional elongation and splicing [7] and stochastic fluctuations [8], to come into play.

LRAs can be classified according to their mechanisms of action, for example LRAs that act epigenetically, and T-cell activators [6]. Epigenetic activators studied have included histone deacetylase (HDAC) inhibitors [9-13], DNA methylation inhibitors [14], and bromodomain/extraterminal domain (BET) inhibitors [15]. T cell activator LRAs include agents that act through conventional T cell activation pathways [16], such as IL-2 and the OKT3 monoclonal antibody (mAb) against CD3 [17]; diacyl glycerol analog protein kinase C (PKC) agonists, such as phorbol esters (e.g., phorbol 12-myristate 13-acetate, TPA, or PMA, reviewed in [18,19]); less toxic cell activators like bryostatin-1 [20]; and potentially mTOR [21] and JAK inhibitors [6,22]. Most T cell activators act through the NF- $\mathrm{kB}$ pathway, releasing activating NF-KB subunits from $\mathrm{IkB} \alpha$ for transit to the nucleus, with subsequent increases in HIV transcriptional initiation [19]. HIV activation strategies employing cytokines and chemokines, working through NF-kB, have long been studied [17,23-26]. However, such agents have toxicities that make them clinically unacceptable or were shown to be ineffective against the latent reservoir in vivo, or both. Small molecules have also been used to activate HIV via NF-kB-related pathways. The best known of these is the diacylglycerol mimetic phorbol myristyl actetate (PMA, TPA) [27] and its derivatives [28-30], but phorbol esters are oncogenic and induce reactive oxygen species targets. Even the less toxic derivatives still show significant toxicity and a poor ability to target the latent reservoir $[18,19,28]$. Agents mechanistically related to known LRAs that have specificity for latent reservoir cells or specificity for HIV activation, compared to non-HIV activation targets, could serve as more effective and less toxic LRAs, useful alone or in combination with other HIV activators.

For expression, the HIV promoter, the long terminal repeat (LTR), requires basal cellular transcription factors, plus inducible factors, notably NF- $\kappa$ B family members, and other host cell factors [27,31-38]. Other cellular activation-dependent, cell-type dependent, or differentiation-dependent factors also contribute to LTR activity [39-45]. NF- $\mathrm{B}$ has long been known as a key gene expression regulator for many cells [46-49]. Five different related factors comprise the NF-кB family: p50, p53, p65 (RelA), c-Rel, and RelB. The proteins share an N-terminal Rel-homology (RHD) domain involved in DNA binding and homo- and hetero-dimerization. NF- $\mathrm{kBs}$ bind as dimers to their binding sites in promoters. Some NF- $\mathrm{kBs}$, when bound to promoters, recruit co-activators and co-repressors, including HIV LTR activators. Three NF-kBs: p65, c-Rel, and RelB, have C-terminal transcription activation domains (TAD) which mediate interactions with activators. Homodimers of p50 or p52, which lack TADs, inhibit transcription. In unactivated HIV LTRs, NF- $\mathrm{BB}$ p50 homodimers bind LTR NF- $\mathrm{kB}$ sites, inhibiting expression, a phenomenon that also involves recruitment of HDACs to the LTR [50]. Upon stimulation, inhibitory p50 homodimers are displaced by TAD-containing NF-kBs (e.g., p50/p65, p50/c-Rel heterodimers), activating expression [51,52]. Different TAD-containing NF- $\mathrm{BBs}$ can partially compensate for each other if one or the other has been knocked out or mutated, but the different TAD-containing NF- $\mathrm{kB}$ subunits have distinct specificities and, presumably, functions within the cell $[53,54]$.

In the absence of stimulation, NF- $\kappa \mathrm{B}$ proteins are held in the cytoplasm, complexed as inactive

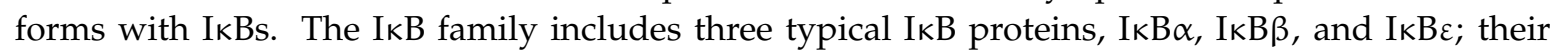
precursor proteins, p100 and p105; and two atypical IкB proteins, Bcl-3 and $\mathrm{I} \kappa \mathrm{B} \zeta$ [49]. The two atypical $\mathrm{I} \kappa \mathrm{B}$ proteins, $\mathrm{Bcl}-3$ and $\mathrm{I} \kappa \mathrm{B} \zeta$, have less clearly understood functions [55-58]. The TNF $\alpha$ pathway for NF- $\kappa B$-dependent activation offers a classical example of transcriptional activation via NF- $\mathrm{B}[48,49]$. In a simplified account, TNF $\alpha$ binds to its receptor, TNF-R, which recruits adaptor proteins (TRAFs and RIP) that interact with TNF-R cytoplasmic domains. TRAFs and RIP recruit an IKK complex, which includes the NEMO scaffold protein and $\alpha$ and $\beta$ catalytic IKK subunits, to activate the complex. 
Activated IKK phosphorylates an IKB, initiating ubiquitination and proteamsome degradation, releasing $\mathrm{NF}-\mathrm{kBs}$ that transit to the nucleus and activates gene expression.

The I $\mathrm{kBs}$ have different functions and activities. I $\mathrm{B} \alpha$ is the best understood. Most cytoplasmic p65/p50 heterodimers bind I $\mathrm{\kappa} B \alpha$. NF- $\kappa B$ can activate I $\kappa \mathrm{B} \alpha$ expression, creating a negative feedback loop [59,60]. IкB $\alpha$ knockout (KO) mice have a severe phenotype [61], dying at 7-10 days of age. I $\kappa \mathrm{B} \alpha$-deficient fibroblasts respond to TNF $\alpha$ and maintain NF- $\kappa B$ in the cytoplasm prior to stimulation, suggesting that other IкBs compensate, but NF- $\kappa B$ nuclear localization is longer. I $\kappa B \beta$ 's function is less clear. The IкB $\beta$ promoter does not respond to cell stimulation. IкB $\beta$ binds p 65 and C-rel

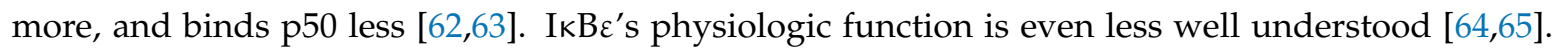
$\mathrm{I} \kappa \mathrm{B} \varepsilon$ is expressed mainly in T cells of the thymus, spleen, and lymph nodes [66], which coincide with the locations of key reservoirs of latent HIV. I $\kappa \mathrm{B} \varepsilon \mathrm{KO}$ mice have a relatively normal phenotype vs. the lethal phenotype of $\mathrm{I} \kappa \mathrm{B} \alpha \mathrm{KO}$ mice [66]. I $\kappa \mathrm{B} \varepsilon \mathrm{KO}$ mice are identical to wildtype mice in appearance and histology, and breed normally. The main differences between them are decreased CD44-CD25+ $\mathrm{T}$ cells, and increased production of IL- $1 \alpha$, IL-1 $\beta$, IL-1R $\alpha$, and IL- 6 mRNAs in macrophages. Since IKB $\varepsilon$ $\mathrm{KO}$ mice have a minimal phenotype, pharmacologic targeting of $\mathrm{I} \kappa \boldsymbol{B} \varepsilon$ is expected to be relatively safe.

We previously conducted a systematic small interfering RNA (siRNA) knockdown study targeting the major IkBs $(\operatorname{IkB} \alpha, \operatorname{IkB} \beta$, and IkBE), to investigate how the different IkBs might help mediate HIV-1 latency [67]. We found that knocking down IkB $\beta$ did not activate HIV-1, and knocking down IkB $\alpha$ activated HIV-1, as expected. We unexpectedly found that knocking down IkB $\varepsilon$ was much more effective at activating HIV-1 than knocking down IkB $\alpha$. Since $I k B \varepsilon$ is highly expressed in cells and tissues that harbor a large fraction of the HIV latent reservoir [66], and since IkB $\varepsilon$ knockout $(\mathrm{KO})$ mice have a minimal phenotype [59,66], HIV activation strategies specifically targeting IkB $\varepsilon$ could plausibly play a helpful role in activating HIV in "shock and kill" HIV reservoir attack strategies.

If targeting IkB $\varepsilon$ were to be explored as a more specific HIV activation strategy, it would be helpful to have a better understanding of the mechanisms responsible for the effective activation of $\mathrm{HIV}$ by IkB$\varepsilon$. LRAs specifically targeting the IkB-NF- $\mathrm{kB}$ pathway, like prostratin and bryostatin, are directed to the $\mathrm{IkB} \alpha-\mathrm{NF}-\mathrm{kB}$ pathway with understandable consequences for enhanced toxicity and a lack of specificity. Here, we show that when we knock down IkBe, we observe, as before, potent HIV activation [67]. We also show that the activation due to IkB $\varepsilon$ knockdown is associated with the transit to the nucleus of activating c-Rel and p65 subunits, and increased binding of these NF- $\mathrm{kBs}$ to the HIV LTR. These findings, along with the more prolonged knockdown kinetics of IkB $\varepsilon$ that we previously observed [67], and the knowledge that $\mathrm{IkB} \varepsilon$ is abundantly expressed in cell types that constitute the latent reservoir and the minimal phenotype of IkBe knockout mice, lends additional support to the possibility of specifically targeting IkB $\varepsilon$ to activate HIV-1 in the context of a "shock and kill" HIV reservoir depletion strategy.

\section{Materials and Methods}

\subsection{Cell Lines and Transfection}

We utilized a latently infected promonocytic cell line, U1 [68] derived from chronically infected U937, and lymphocytic cell lines J1.1 and ACH-2 cells [69-71]. The cells were seeded $24 \mathrm{~h}$ prior to transfection at a cell concentration of $2 \times 10^{5}$ cells/mL in RPMI (Life Technologies, Carlsbad, CA, USA) with 1\% L-glutamine (Life Technologies), 10\% fetal bovine serum (FBS) (Hyclone), $100 \mathrm{IU} / \mathrm{mL}$ penicillin, and $100 \mu \mathrm{g} / \mathrm{mL}$ streptomycin (Sigma, St. Louis, MO, USA) in $5 \% \mathrm{CO}_{2}$ at $37^{\circ} \mathrm{C}$. On the day of transfection, specific siRNAs at the desired concentrations were mixed with 2 million U1 cells, resuspended in Nucleofector solution (Lonza, Alpharetta, GA, USA), and transfected using Nucleofactor 2D. Once transfected, cells were transferred to $60 \mathrm{~mm}$ dishes that contained $3 \mathrm{~mL}$ of pre-warmed 1 phosphate-buffered saline (PBS). Plates were incubated for $3 \mathrm{~h}$ in $5 \% \mathrm{CO}_{2}$ at $37{ }^{\circ} \mathrm{C}$. Cells were transferred to a $5 \mathrm{~mL}$ tube and centrifuged at $1200 \mathrm{rpm}$ for $5 \mathrm{~min}$. The cell pellets were resuspended in $7 \mathrm{~mL}$ RPMI supplemented with $10 \%$ FBS, and incubated in a $60 \mathrm{~mm}$ dish for $36 \mathrm{~h}$ at $37^{\circ} \mathrm{C}$. 
Twenty four hours post transfection, $750 \mu \mathrm{L}$ culture was taken to extract total RNA using an RNeasy Mini Kit (Qiagen, Germantown, MD, USA). Thirty six hours post transfection, cells were pelleted, and supernatants were stored at $-80^{\circ} \mathrm{C}$ for further use. Knockdown efficiencies observed in these studies were comparable in the data presented here, and in additional and previously published experiments [67].

\subsection{Nuclear and Cytoplasmic Extract Preparation}

A total of 5-8 $\times 10^{6} \mathrm{U} 1$ cells were harvested $36 \mathrm{~h}$ after siRNA transfection and washed with ice cold $1 \times$ PBS. Nuclear and Cytoplasmic extracts were prepared using NE-PER ${ }^{\mathrm{TM}}$ Nuclear and Cytoplasmic Extraction Reagents (Thermo Fisher Scientific, Rockford, IL, USA) according to the manufacturer's instructions. The protein extracts were estimated using Bradford reagent (BioRad, Hercules, CA, USA) according to the manufacturer's instructions and equal amounts (15-20 $\mu \mathrm{g})$ of nuclear and cytoplasmic extracts were used for immunoblot.

\subsection{Immunoblotting}

For protein isolation, the cell pellet was lysed in TN-lysis buffer $(20 \mathrm{mM}$ Tris-Cl, $150 \mathrm{mM} \mathrm{NaCl}$, $1 \mathrm{mM}$ EDTA, $0.5 \mathrm{mM}$ PMSF, $0.5 \% \mathrm{NP}-40$, and $1 \times$ protease inhibitor) by incubating for $45 \mathrm{~min}$ on ice with intermittent agitation. The samples were centrifuged at $13,000 \mathrm{rpm}$ for $15 \mathrm{~min}$ at $4{ }^{\circ} \mathrm{C}$ and clarified lysates were transferred to the fresh tubes. The protein present in the clarified lysate was estimated using a Bradford assay (BioRad), according to the manufacturer's instructions. Twenty five micrograms of the total clarified isolated protein was mixed with a $4 \times$ Laemmli buffer, heated at $95^{\circ} \mathrm{C}$ for $10 \mathrm{~min}$, and loaded on a NuPAGE 4-12\% Bis-Tris pre-cast gel (Life technologies). Proteins were transferred onto a nitrocellulose membrane $(0.45 \mu \mathrm{m}$, BioRad) using $1 \times$ NuPAGE Transfer Buffer (Invitrogen Life Technologies, Carlsbad, CA, USA). The blots were blocked with $5 \%$ non-fat milk for $1 \mathrm{~h}$ prior to immunoblotting with anti-GAPDH (Abcam), anti-Lamin A/C (Peirce), anti-p65 (Abcam), anti-c-Rel (Abcam), and anti-HIV Gag-p24 (AIDS Reagent Program). Proteins were detected with goat anti-mouse IgG-HRP (Invitrogen), goat anti-rabbit IgG-HRP, and chemiluminescent substrate (Thermo Scientific). Immunoblots were imaged using a ChemiDoc MP instrument (BioRad). Composite figures were produced in Affinity Photo and Affinity Designer.

\subsection{Chromatin Immunoprecipitation Assay (ChIP)}

Chromatin immunoprecipitation (ChIP) assays were performed using ChIP-IT Express Enzymatic Kit (ActiveMotif, Carlsbad, CA, USA) according to the manufacturer's instructions. Briefly, 5-8 $\times 10^{6}$ $\mathrm{U} 1$ cells were fixed $36 \mathrm{~h}$ post transfection in $1 \%$ formaldehyde for $15 \mathrm{~min}$ at room temperature. The fixed cells were then washed using wash buffer $1(0.25 \%$ Triton X-100, $10 \mathrm{mM}$ EDTA, $0.5 \mathrm{mM}$ ethylene glycol bis( $\beta$-aminoethyl ether) $\mathrm{N}, \mathrm{N}^{\prime}$-tetraacetic acid, $10 \mathrm{mM}$ HEPES (pH 7.5), 1 mM PMSF, $10 \mathrm{mM}$ sodium butyrate, and $2 \times$ protease inhibitor cocktail) and wash buffer $2(0.2 \mathrm{M} \mathrm{NaCl}, 1 \mathrm{mM}$ EDTA, $0.5 \mathrm{mM}$ ethylene glycol bis( $\beta$-aminoethyl ether) $\mathrm{N}, \mathrm{N}^{\prime}$ - tetraacetic acid, $10 \mathrm{mM}$ HEPES (pH 7.5), $1 \mathrm{mM}$ PMSF, $10 \mathrm{mM}$ sodium butyrate, and $2 \times$ protease inhibitor cocktail) and lysed in lysis buffer (1\% SDS, $10 \mathrm{mM}$ EDTA, and $50 \mathrm{mM}$ Tris- $\mathrm{HCl}(\mathrm{pH} 8.1))$. Sonication cycles $(10 \times 10 \mathrm{~s}$ with $10 \mathrm{~s}$ hold on ice between each pulse) were then performed to shear chromatin using a Bioruptor (ActiveMotif). The lysate was precleared with protein A/G beads (ActiveMotif); and the precleared lysate was immunoprecipitated with mouse antihuman RNA Pol II antibody, or with the negative control IgG (ActiveMotif). The immune complexes were then pulled down by protein A/G beads and washed thrice with RIPA wash buffer $(0.1 \%$ SDS, $1 \%$ sodium deoxycholate, $150 \mathrm{mM} \mathrm{NaCl}, 10 \mathrm{mM}$ sodium phosphate (pH 7.2), 2 mM EDTA, and 1\% IGEPAL) and then thrice with TE (10 mM Tris ( $\mathrm{pH} 8.0)$ and $1 \mathrm{mM}$ EDTA). Elution of the complexes were then performed in $0.1 \mathrm{M} \mathrm{NaHCO}_{3}, 0.1 \% \mathrm{SDS}$, and $10 \mathrm{mM}$ DTT. DNA was extracted after reverse cross-linking, proteinase $\mathrm{K}$ treatment, and phenol chloroform extraction. The eluted DNA was dissolved in $50 \mu \mathrm{L}$ of $1 \times$ TE. ChIP-PCR was performed in a $25 \mu \mathrm{L}$ reaction mixture containing $1 \times$ Real-time PCR master mix (Promega, Madison, WI, USA) 
and 10 pmol of LTR primers (ChIP2_LTR_f: 5'-CCGAGAGCTGCATCCGGAGT-3', ChIP2_LTR_r: 5'-ACTGCTAGAGATTTTCCACACT-3').

\subsection{HIV-1 RNA Quantitation}

Total RNA was extracted from the cell pellets $24 \mathrm{~h}$ after siRNA transfection, using an RNeasy Mini Kit (Qiagen) according to the manufacturer's instructions. The extracted RNA was quantified using a NanoDrop HD1000 Spectrophotometer (Thermo Scientific). The purity of the RNA samples was estimated based on the 260:280 absorbance ratio, and samples were required to have ratios $\geq 2$. $500-750 \mu \mathrm{g}$ of total RNA per sample was used for reverse transcription reactions using iScript ${ }^{\mathrm{TM}}$ Reverse Transcription Supermix for qRT-PCR (Bio-Rad) according to the manufacturer's protocol. Briefly, the RNA was mixed with $4 \mu \mathrm{L}$ of $5 \times$ iScript RT Supermix, and RNase-free water (Qiagen) was added to the reaction to make up a volume of $20 \mu \mathrm{L}$. For negative control or no reverse transcriptase control (NRTC) reactions, we used a reaction mixture made by mixing RNA, water, and $4 \mu \mathrm{L}$ of $5 \times$ iScript no-RT Supermix. The reactions were incubated for $5 \mathrm{~min}$ at $25^{\circ} \mathrm{C}$ for primer annealing, $60 \mathrm{~min}$ at $42{ }^{\circ} \mathrm{C}$ for reverse transcription, and then at $85^{\circ} \mathrm{C}$ for $5 \mathrm{~min}$ for enzyme inactivation in a Thermal Cycler (Bio-Rad). The cDNA reactions were diluted tenfold, and $2 \mu \mathrm{L}$ of diluted cDNA was used in real time PCR reactions. For the qPCR reactions, we used the TaqMan master mix system (Applied Biosystems, Foster City, CA, USA), TaqMan probes specific for HIV-1 late RNA (unspliced RNA) (IDT), and human GAPDH (Applied Biosystems). The sequences of primer sets used to amplify HIV-1 unspliced RNA were 5'-ATAATCCACCTATCCCAGTAGGA GAAAT- $3^{\prime}$ and 5'TTTGGTCCTGTGCTT ATGTCCAGAATGC [72]. A FAM-TAMRA-labeled probe, 5'-ATCCTGGGATTCAATAAAATAGTAGAGATGTATAGCCCTAC-3' , was used for quantitation of late viral RNA species [67]. The thermal cycling conditions were $50{ }^{\circ} \mathrm{C}$ for $2 \mathrm{~min}$, and an initial denaturation at $95{ }^{\circ} \mathrm{C}$ for $15 \mathrm{~s}$, followed by 40 cycles at $95{ }^{\circ} \mathrm{C}$ for $15 \mathrm{~s}$, and $60{ }^{\circ} \mathrm{C}$ for $60 \mathrm{~s}$ using the Applied Biosystems 7500 Fast Real Time PCR detection system. All reactions were performed in $20 \mu \mathrm{L}$ final volume, with human GAPDH used as endogenous control, and NRTC as negative control. The amount of PCR product was determined by the comparative $2^{-\Delta \Delta C t}$ method [73], with each sample normalized to human GAPDH and expressed as a fold-increase versus untreated controls.

\subsection{Image Quantitation}

Quantitative data was extracted from gel images using ImageJ version 2.0.0-rc-69/1.52p, using the FIJI interface, with included plugins.

\subsection{Statistical Analyses}

Statistical analyses were conducted using log-transformed values, 2-tailed Student's $t$-test, 2-sample unequal variance, using Excel and $\mathrm{R}$ (version 3.6.1) with the RStudio user interface and the tidyverse package. Experiments were repeated at least three times, with representative gels shown. Some graphs were also generated with Graphpad. Error bars shown, indicate standard deviations.

\section{Results}

To explore the mechanisms underlying the large increases in HIV expression seen particularly when $\mathrm{I} \kappa \mathrm{B} \varepsilon$ is knocked down, we confirmed that $\mathrm{I} \kappa \mathrm{B} \varepsilon$ siRNA knocks down I $\mathrm{KB} \varepsilon$ expression at the RNA and protein levels; showed that I $\kappa \mathrm{B} \varepsilon$ knockdown is associated with HIV activation; and determined cytoplasmic and nuclear localization of two activating, canonical examples of TAD-containing NF- $\mathrm{kB}$ subunits from the Rel and NF-B families, c-Rel and p65. c-Rel and p65 are activated via inflammatory and pathogenic signals that are thought to be likely mediators of HIV activation [74]. 


\section{1. siRNA Transfection and HIV Transcription Activation}

To determine the effects of $I \kappa B \alpha$ and $I \kappa B \varepsilon$ siRNA on $I \kappa B \alpha, I \kappa B \varepsilon$, and HIV expression at the RNA level, we transfected the different IKB siRNAs into U1 cells latently infected with HIV in parallel, along with a control siRNA, while also treating cells in parallel with PMA as a positive control. We isolated RNA and assayed for I $\kappa \mathrm{B} \alpha, \mathrm{I} \kappa \mathrm{B} \varepsilon$, and HIV p24 RNA using a qPCR assay (Figure 1). We found that $\mathrm{I} \kappa \mathrm{B} \alpha$ siRNA transfection was associated with a decrease in $\mathrm{I} \kappa \mathrm{B} \alpha \mathrm{RNA}$; minimal decrease in I $\mathrm{B} \varepsilon$ RNA and $\mathrm{I} \kappa \mathrm{B} \varepsilon$ siRNA transfection was associated with a strong decrease in I $\mathrm{B} \varepsilon$ RNA; and minimal decrease in $I \kappa B \alpha$. The results also indicated good specificity and minimal crosstalk between the effects of the $I \kappa B \alpha$ and $I \kappa B \varepsilon$ siRNAs. Interestingly, PMA treatment was associated with decreased I $\kappa$ B $\varepsilon$ RNA, but not with decreased I $\kappa \mathrm{B} \alpha$ RNA, reflecting the feedback loops involved in the NF- $\mathrm{B}$-dependent pathways regulating the $\mathrm{I} \kappa \mathrm{B} \varepsilon$ expression, and providing additional rationale for the strong increases in HIV expression observed with PMA treatment. I $\kappa \mathrm{B} \alpha$ siRNA increased HIV expression, but I $\kappa$ B $\varepsilon$ siRNA increased HIV expression almost twice as much. PMA is well-established as an agent that dramatically increases HIV expression [17,23-27].
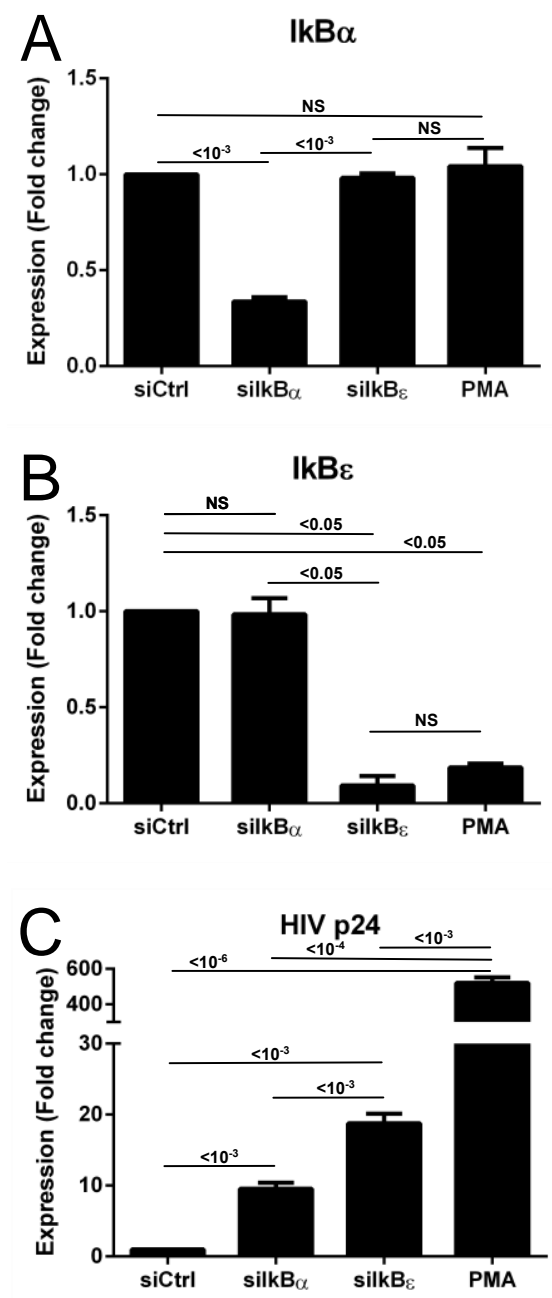

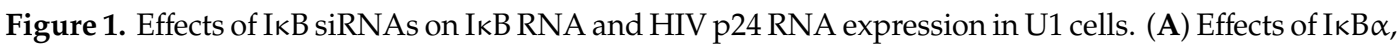
$\mathrm{I} \kappa \mathrm{B} \varepsilon$, and control siRNA, and positive control activator PMA on I $\mathrm{B} \alpha$ RNA expression. (B) Effects of $\mathrm{I} \kappa \mathrm{B} \alpha, \mathrm{I} \kappa \mathrm{B} \varepsilon$, and control siRNA, and positive control activator PMA on I $\mathrm{B} \varepsilon$ RNA expression. (C) Effects of $\mathrm{I} \kappa \mathrm{B} \alpha, \mathrm{I} \kappa \mathrm{B} \varepsilon$, and control siRNA, and positive control activator PMA on HIV p24 RNA expression. $P$-values, per two-tailed Student $t$-test performed on log-transformed values with unequal variance, are indicated on the graphs. 


\subsection{I $I \kappa \alpha$ and $I \kappa B \varepsilon$ siRNA Transfection and $I \kappa B \alpha$ and $I \kappa B \varepsilon$ and HIV Protein Expression}

To confirm that $\mathrm{I} \kappa \mathrm{B} \alpha$ and $\mathrm{I} \kappa \mathrm{B} \varepsilon$ siRNAs had their expected effects at the protein level for the expression of the IкBs and for HIV protein expression, and was similar in several cell line models of latent HIV infection, we transfected I $\kappa \mathrm{B} \alpha$ and I $\kappa \mathrm{B} \varepsilon$ siRNAs into U1, ACH-2, and J1.1 cells; made whole cell protein extracts from the cells; and used immunoblots to test for IкB $\alpha$ and IкB $\varepsilon$ proteins, HIV p55 and HIV p24, with GAPDH as control. Figure 2A shows a composite of the different immunoblots. Figure 2B shows graphs of the quantitation of the bands, normalized to the GAPDH control, and then normalized to the maximum expression of each band in each cell line transfected with the indicated siRNA. I $\kappa B \alpha$ siRNA decreased I $\kappa$ B $\alpha$ protein in all the cell lines, and I $\kappa B \varepsilon$ siRNA also decreased $\mathrm{I} \kappa \mathrm{B} \varepsilon$ protein in all cell lines. Both $\mathrm{I} \kappa \mathrm{B} \alpha$ and $\mathrm{I} \kappa \mathrm{B} \varepsilon$ siRNA transfection were associated

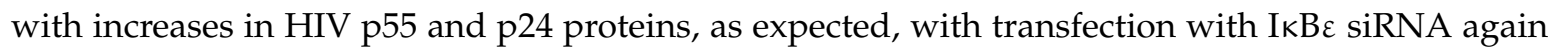
associated with a larger increase in HIV protein expression.

A

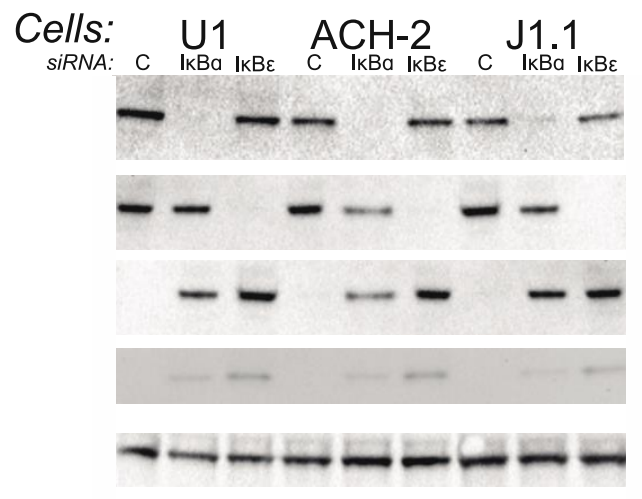

B

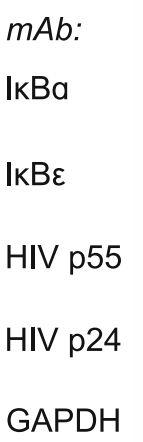

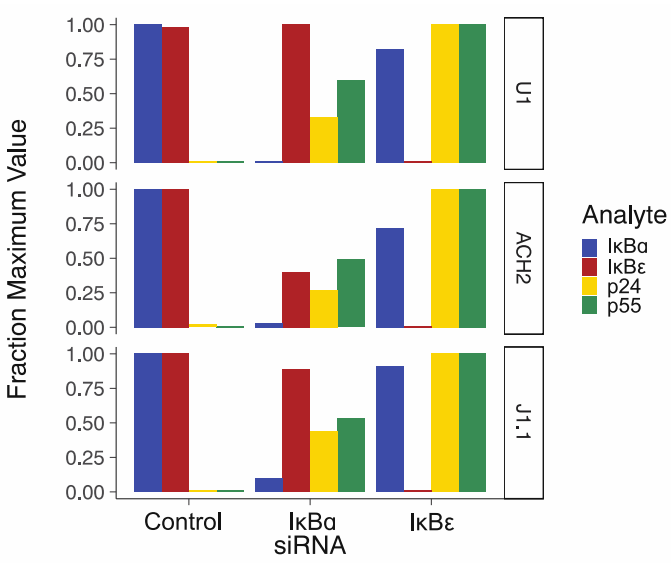

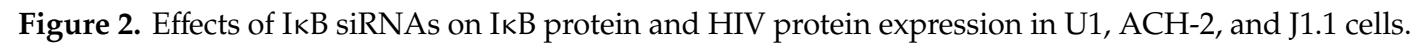
(A) Composite immunoblot. Cell lines used in this experiment are indicated at the top of the figure, with the individual siRNA used in the experiments run in each lane indicated beneath. The designations to the right of the figure indicate the target of the mAb used for each immunoblot. (B) Immunoblot quantitation. Bands from panel A were quantitated using ImageJ normalized to the GAPDH control, and then for each condition, normalized against the condition yielding the maximum value. The fraction of the maximum values for each condition are indicated on the left side of the panel, cell lines are indicated on the right side of the panel, and the control and/or siRNAs transfected in each experiment are indicated at the bottom of the panel.

\subsection{Nuclear Translocation of Activating NF- $\kappa B$ Subunits Associated with Transfection of I $\kappa \alpha$ and $I \kappa B \varepsilon$ siRNAs}

To determine whether knocking down $\mathrm{I} \kappa \mathrm{B} \alpha$ and $\mathrm{I} \kappa \mathrm{B} \varepsilon$ was associated with transit of the activating NF- $\mathrm{B}$ subunits from the cytoplasm to the nucleus (which were required for HIV activation), we transfected $\mathrm{I} \kappa \mathrm{B} \alpha$ and $\mathrm{I} \kappa \mathrm{B} \varepsilon$ siRNAs and a control siRNA into U1 cells and conducted a nuclear/cytoplasmic split, and then evaluated the resulting protein extracts using immunoblots (Figure 3A,B). The results show that nuclear/cytoplasmic split was successful, with the cytoplasmic marker detectable in the protein extracts from the cytoplasmic fractions only, and the nuclear marker Lamin A/C observed in the nuclear fractions only. We found that the c-Rel NF- $\mathrm{B}$ subunit was observed in both the cytoplasmic and nuclear fractions, but that transfection with the I $\mathrm{B} \varepsilon$ siRNA was associated with greater amounts of $\mathrm{c}-\mathrm{Rel}$ in the nucleus. We detected only minimal amounts of the p65 NF- $\mathrm{kB}$ subunit in the cytoplasm $36 \mathrm{~h}$ after transfection with $\mathrm{I} \kappa \mathrm{B} \alpha$ and $\mathrm{I} \kappa \mathrm{B} \varepsilon$ siRNAs, with a large increase in the nucleus of the p65 NF- $\kappa B$ subunit after $\mathrm{I} \kappa \mathrm{B} \alpha$ siRNA transfection, and a larger increase in p65 after transfection with $\mathrm{I} \kappa \mathrm{B} \varepsilon$ siRNA. 


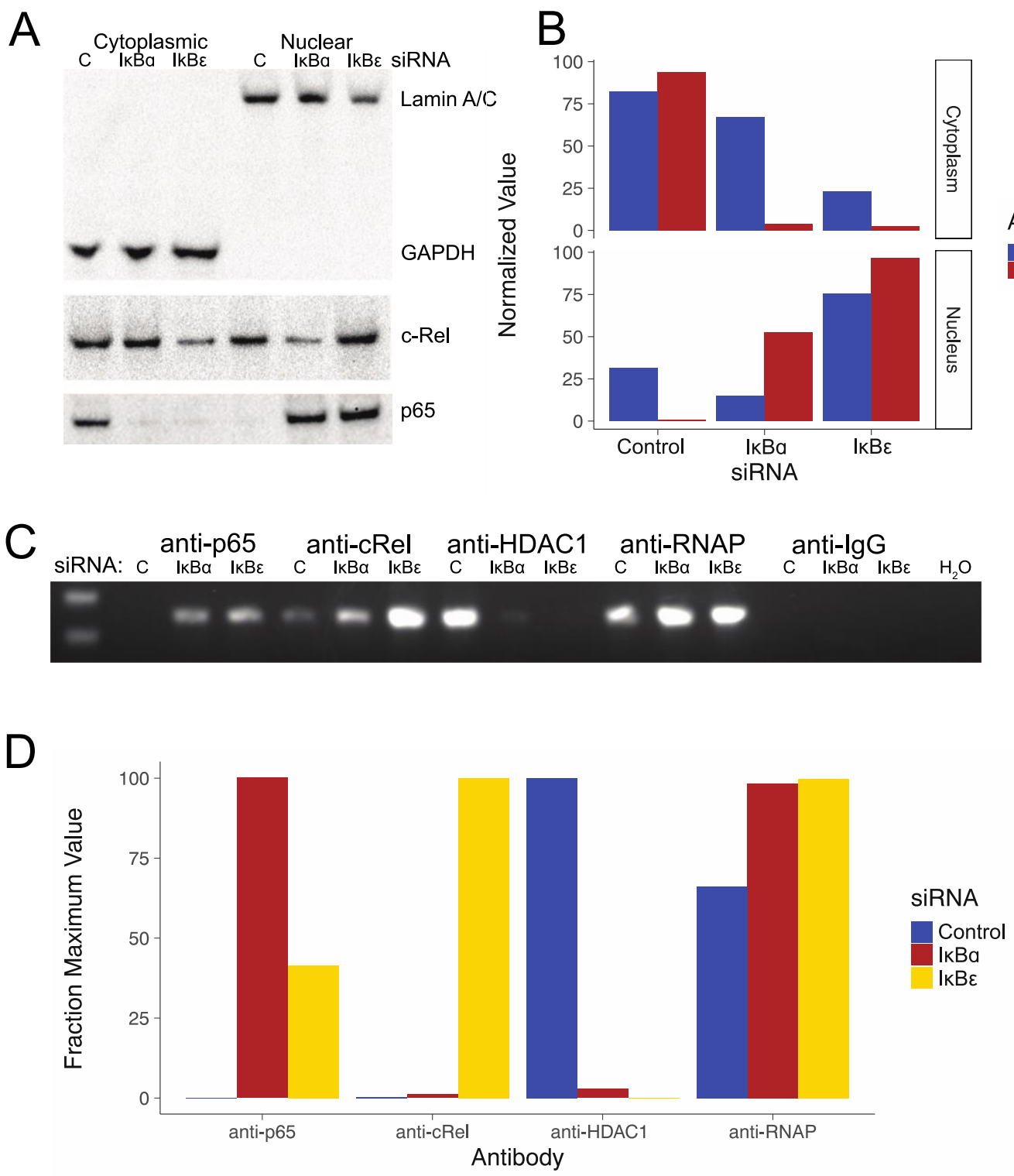

Figure 3. Nuclear transit and chromatin immunoprecipitation assays of NF- $\kappa B$ subnits following I $\kappa B$ knockdown. (A) Assays showing transit from cytoplasm to nucleus of NF- $k$ B subunits, c-Rel and $\mathrm{p} 65$, following transfection of the cells with $\mathrm{I} \kappa \mathrm{B} \alpha$ and $\mathrm{I} \kappa \mathrm{B} \varepsilon$ siRNAs. The origin of the protein extracts, cytoplasmic or nuclear, is indicated at the top of the figure. The designators on the right side of the figure indicate the mAb use for the immunoblot. (B) Quantitation of the bands from panel A-nuclear transit experiments. The c-Rel and p65 bands were normalized to the GAPDH loading control band for the cytoplasmic samples and/or the Lamin A/C loading control band, and then multiplied by an arbitrary constant to expand the range for each set of assays to 100. The normalized values (arbitrary units) are shown on the left, the cytoplasmic or nuclear compartment sources are indicated on the right side of the figure, and the siRNA used in each experiment is indicated at the bottom of the panel. (C) HIV LTR chromatin immunopreciptation assays for NF-kB subunits. c-Rel and p65, following transfection of the cells with $I \kappa B \alpha$ and I $\kappa B \varepsilon$ siRNAs. The top line indicates the primary mAb used in the immunopreciptation, while the indicators on the line beneath indicates the siRNA transfected into the cells to generate the extract assayed in the reactions run in each lane. (D) Quantitation for the chromatin immunopreciptation assays. The bands from panel $\mathrm{C}$ were scanned and quantitated, and then for each antibody, normalized to the condition of maximum signal set as 100 percent for each antibody, since the ChIP assays performed using each antibody cannot be directly quantitatively compared with each other. Quantitations were not performed for the anti-IgG and $\mathrm{H}_{2} \mathrm{O}$ negative controls because the scanned values for these lanes were essentially zero. 


\subsection{HIV LTR NF- $\kappa B$ Chromatin Immunoprecipitation After Transfection of $I \kappa B \alpha$ and I $\kappa B \varepsilon$ siRNAs}

To determine whether there were differences in the binding of the activating NF- $\mathrm{kB}$ subunits to

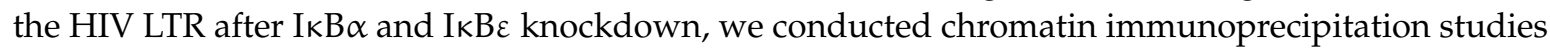
following the transfection of $I_{\kappa} B \alpha$ and $I \kappa B \varepsilon$ siRNAs (Figure 3C,D). We found that transfection of the $I_{\kappa} B \alpha$ and $I \kappa B \varepsilon$ siRNAs was associated with a large increase in the binding of the activating NF- $\kappa B$ subunits c-Rel and p65, to the HIV LTR, compared to transfection with control siRNA; a large decrease in HDAC1 bound to the LTR, compared to transfection with control siRNA; and a modest increase in the binding of RNAP to the LTR.

\section{Discussion}

Taken together, the results we report in this study and in our earlier study [67] are consistent with

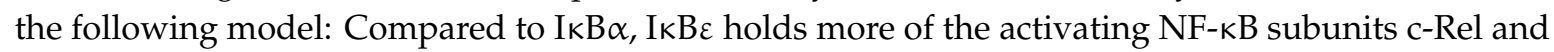
p65. Therefore, when I $\mathrm{K} B \varepsilon$ is knocked down, these activating NF- $k B$ subunits transit to the nucleus where they bind to the HIV LTR, yielding an activating set of NF-kB subunits bound to the HIV LTR, leading to a large increase in HIV gene expression.

Limitations of this study include the fact that we used cell lines, U1, ACH-2, and J1.1. The U1 and ACH-2 cell lines have an altered Tat-TAR axis [75,76]. However, these alterations in Tat-TAR would not affect initial activation via NF- $\mathrm{KB}$. If anything, the Tat-TAR alterations would lessen activation and help maintain latency, so evidence of effective activation via I $\mathrm{B} \varepsilon$ knockdown would be expected to be potent in cell lines without Tat-TAR alterations, as observed with the J1.1 cell line in this report and in our previous work [67]. Overall, the results were similar in all the cell lines tested, and were consistent with activation observed in our prior study [67].

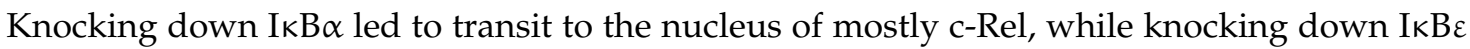
led to the nuclear transit of larger amounts of both c-Rel and p65 (Figure 3A,B), with more p65 than c-Rel. Both p65 and c-Rel have TADs and so can form an activating heterodimer with, for example,

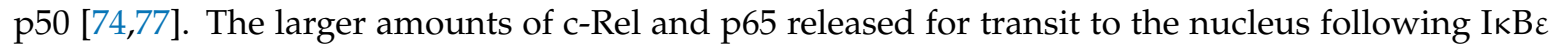

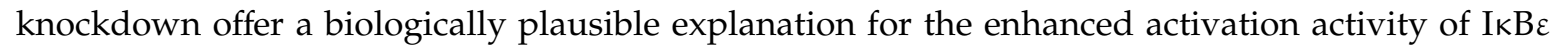
knockdown, particularly since an activating heterodimer with p50 can be formed with either c-Rel or p65, so releasing activating NF- $\kappa$ Bs from a single $I \kappa B \varepsilon$ can yield two activating heterodimers.

In some cell lines (ACH-2, J1.1) the efficiency of IKB $\varepsilon$ knockdown was slightly better than I $\mathrm{B} \alpha$. In $\mathrm{U} 1$ cells, the knock down abilities of the IkB $\alpha$ and I $\mathrm{I} B \varepsilon$ siRNAs were essentially equivalent (Figure 1 ), yet $\mathrm{I} \kappa \mathrm{B} \varepsilon$ siRNA was a more efficient HIV activator in the U1 cells, as well as in the ACH-1 and J1.1 cell lines, arguing that specifically targeting IKB $\varepsilon$ as an HIV activating strategy could be potentially helpful. However, even if $I \kappa B \varepsilon$ knockdown was less efficient than $I \kappa B \alpha$ knockdown, the likely high therapeutic

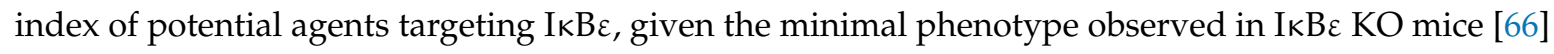
as well as the slower resynthesis kinetics of $\mathrm{I} K B \varepsilon$ [67], suggests that further efforts aimed at developing therapeutics targeting IKB $\varepsilon$ for HIV activation could be helpful.

While many HIV LARs for use in "shock and kill" strategies to attack and deplete the reservoir of long term latently infected cells have been studied, none have really been proven to be clinically safe and effective $[1-6,16,18,19]$. This unfortunate experience suggests that it might be helpful to pursue mechanistically novel latency activation technologies for use in "shock and kill." Indeed, it may be necessary ultimately to combine multiple therapeutics targeting several different latency activation mechanisms (DNA methylation and HDAC inhibitors, P-TEFb releasing agents, histone methyl transferase inhibitors, as well as agents targeting the NFKB system) to effectively accomplish the "shock" of the "shock and kill" approach to HIV reservoir depletion [78]. Given the toxicity exhibited by more traditional agents targeting the NFKB system, such as phorbol esters and their derivatives, and inflammatory cytokines, a more gentle and specific approach narrowly targeting IKB $\varepsilon$ alone could prove useful for an NFKB component of "shock" HIV activators.

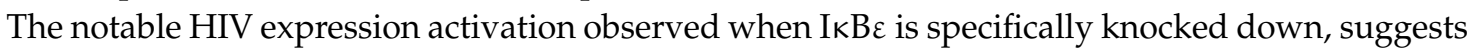
that efforts aimed at developing methods to activate HIV expression for use in "shock and kill" therapies 
through specific targeting of $I \kappa B \varepsilon$ or $I \kappa B \varepsilon-N F-\kappa B$ subunit interactions, as opposed to developing general approaches to activate HIV non-specifically through NF- $\mathrm{kB}$ pathways, might offer a new and potentially effective path to attacking the latent HIV reservoir.

Author Contributions: S.Z.K. helped to conceive, design, perform, and analyze experiments and contributed to the writing. S.G. helped to conduct experiments. S.L.Z. helped to conceive, design, and analyze the experiments, and contributed to the writing, figure preparation, and final editing.

Funding: Funded through the Pendleton Pediatric Infectious Disease Laboratory, University of Virginia.

Conflicts of Interest: A previous employer of the authors (Children's National Medical Center) has an intellectual property interest in the use of targeting $\mathrm{I} \kappa \mathrm{B} \varepsilon$ for HIV activation, and submitted a provisional patent application. The funders had no role in the design of the study; in the collection, analyses, or interpretation of data; in the writing of the manuscript; or in the decision to publish the results.

\section{References}

1. Sengupta, S.; Siliciano, R.F. Targeting the latent reservoir for HIV-1. Immunity 2018, 48, 872-895. [CrossRef] [PubMed]

2. Castro-Gonzalez, S.; Colomer-Lluch, M.; Serra-Moreno, R. Barriers for hiv cure: The latent reservoir. AIDS Res. Hum. Retrovir. 2018, 34, 739-759. [CrossRef] [PubMed]

3. Sung, J.M.; Margolis, D.M. Hiv persistence on antiretroviral therapy and barriers to a cure. Adv. Exp. Med. Biol. 2018, 1075, 165-185. [PubMed]

4. Pitman, M.C.; Lau, J.S.Y.; McMahon, J.H.; Lewin, S.R. Barriers and strategies to achieve a cure for hiv. Lancet HIV 2018, 5, e317-e328. [CrossRef]

5. Archin, N.M.; Sung, J.M.; Garrido, C.; Soriano-Sarabia, N.; Margolis, D.M. Eradicating HIV-1 infection: Seeking to clear a persistent pathogen. Nat. Rev. Microbiol. 2014, 12, 750-764. [CrossRef]

6. Spivak, A.M.; Planelles, V. Novel latency reversal agents for HIV-1 cure. Annu. Rev. Med. 2018, 69, 421-436. [CrossRef]

7. Yukl, S.A.; Kaiser, P.; Kim, P.; Telwatte, S.; Joshi, S.K.; Vu, M.; Lampiris, H.; Wong, J.K. Hiv latency in isolated patient $\mathrm{cd} 4^{+} \mathrm{T}$ cells may be due to blocks in hiv transcriptional elongation, completion, and splicing. Sci. Transl. Med. 2018, 10, eaap9927. [CrossRef]

8. Singh, A.; Weinberger, L.S. Stochastic gene expression as a molecular switch for viral latency. Curr. Opin. Microbiol. 2009, 12, 460-466. [CrossRef]

9. Archin, N.M.; Liberty, A.L.; Kashuba, A.D.; Choudhary, S.K.; Kuruc, J.D.; Crooks, A.M.; Parker, D.C.; Anderson, E.M.; Kearney, M.F.; Strain, M.C.; et al. Administration of vorinostat disrupts HIV-1 latency in patients on antiretroviral therapy. Nature 2012, 487, 482-485. [CrossRef]

10. Laughlin, M.; Zeichner, S.; Kolson, D.; Alwine, J.; Seshamma, T.; Pomerantz, R.; Gonzalez-Scaran, F. Sodium butryate treatment of cells latently infected with hiv-1 results in the expression of unspliced viral rna. Virology 1993, 196, 496-505. [CrossRef]

11. Rasmussen, T.A.; Tolstrup, M.; Brinkmann, C.R.; Olesen, R.; Erikstrup, C.; Solomon, A.; Winckelmann, A.; Palmer, S.; Dinarello, C.; Buzon, M.; et al. Panobinostat, a histone deacetylase inhibitor, for latent-virus reactivation in hiv-infected patients on suppressive antiretroviral therapy: A phase 1/2, single group, clinical trial. Lancet HIV 2014, 1, e13-e21. [CrossRef]

12. Elliott, J.H.; Wightman, F.; Solomon, A.; Ghneim, K.; Ahlers, J.; Cameron, M.J.; Smith, M.Z.; Spelman, T.; McMahon, J.; Velayudham, P.; et al. Activation of hiv transcription with short-course vorinostat in hiv-infected patients on suppressive antiretroviral therapy. PLoS Pathog. 2014, 10, e1004473. [CrossRef] [PubMed]

13. Sogaard, O.S.; Graversen, M.E.; Leth, S.; Olesen, R.; Brinkmann, C.R.; Nissen, S.K.; Kjaer, A.S.; Schleimann, M.H.; Denton, P.W.; Hey-Cunningham, W.J.; et al. The depsipeptide romidepsin reverses HIV-1 latency in vivo. PLoS Pathog. 2015, 11, e1005142. [CrossRef] [PubMed]

14. Bouchat, S.; Delacourt, N.; Kula, A.; Darcis, G.; Van Driessche, B.; Corazza, F.; Gatot, J.S.; Melard, A.; Vanhulle, C.; Kabeya, K.; et al. Sequential treatment with 5-aza-2'-deoxycytidine and deacetylase inhibitors reactivates HIV-1. EMBO Mol. Med. 2016, 8, 117-138. [CrossRef] [PubMed]

15. Lu, P.; Shen, Y.; Yang, H.; Wang, Y.; Jiang, Z.; Yang, X.; Zhong, Y.; Pan, H.; Xu, J.; Lu, H.; et al. Bet inhibitors rvx-208 and pfi-1 reactivate HIV-1 from latency. Sci. Rep. 2017, 7, 16646. [CrossRef] 
16. Bullen, C.K.; Laird, G.M.; Durand, C.M.; Siliciano, J.D.; Siliciano, R.F. New ex vivo approaches distinguish effective and ineffective single agents for reversing HIV-1 latency in vivo. Nat. Med. 2014, 20, 425-429. [CrossRef]

17. Prins, J.M.; Jurriaans, S.; van Praag, R.M.; Blaak, H.; van Rij, R.; Schellekens, P.T.; ten Berge, I.J.; Yong, S.L.; Fox, C.H.; Roos, M.T.; et al. Immuno-activation with anti-CD3 and recombinant human Il-2 in HIV-1-infected patients on potent antiretroviral therapy. AIDS 1999, 13, 2405-2410. [CrossRef]

18. McKernan, L.N.; Momjian, D.; Kulkosky, J. Protein kinase c: One pathway towards the eradication of latent HIV-1 reservoirs. Adv. Virol. 2012, 2012, 805347. [CrossRef]

19. Jiang, G.; Dandekar, S. Targeting NF-kappaB signaling with protein kinase C agonists as an emerging strategy for combating HIV latency. AIDS Res. Hum. Retrovir. 2015, 31, 4-12. [CrossRef]

20. Gutierrez, C.; Serrano-Villar, S.; Madrid-Elena, N.; Perez-Elias, M.J.; Martin, M.E.; Barbas, C.; Ruiperez, J.; Munoz, E.; Munoz-Fernandez, M.A.; Castor, T.; et al. Bryostatin-1 for latent virus reactivation in HIV-infected patients on antiretroviral therapy. AIDS 2016, 30, 1385-1392. [CrossRef]

21. Martin, A.R.; Pollack, R.A.; Capoferri, A.; Ambinder, R.F.; Durand, C.M.; Siliciano, R.F. Rapamycin-mediated mtor inhibition uncouples HIV-1 latency reversal from cytokine-associated toxicity. J. Clin. Investig. 2017, 127, 651-656. [CrossRef] [PubMed]

22. Spivak, A.M.; Larragoite, E.T.; Coletti, M.L.; Macedo, A.B.; Martins, L.J.; Bosque, A.; Planelles, V. Janus kinase inhibition suppresses PKC-induced cytokine release without affecting HIV-1 latency reversal ex vivo. Retrovirology 2016, 13, 88. [CrossRef] [PubMed]

23. Lafeuillade, A.; Poggi, C.; Chadapaud, S.; Hittinger, G.; Chouraqui, M.; Pisapia, M.; Delbeke, E. Pilot study of a combination of highly active antiretroviral therapy and cytokines to induce HIV-1 remission. J. Acquir. Immune Defic. Syndr. 2001, 26, 44-55. [CrossRef] [PubMed]

24. Stellbrink, H.J.; Hufert, F.T.; Tenner-Racz, K.; Lauer, J.; Schneider, C.; Albrecht, H.; Racz, P.; van Lunzen, J. Kinetics of productive and latent hiv infection in lymphatic tissue and peripheral blood during triple-drug combination therapy with or without additional interleukin-2. Antivir. Ther. 1998, 3, 209-214. [PubMed]

25. Dybul, M.; Hidalgo, B.; Chun, T.W.; Belson, M.; Migueles, S.A.; Justement, J.S.; Herpin, B.; Perry, C.; Hallahan, C.W.; Davey, R.T.; et al. Pilot study of the effects of intermittent interleukin-2 on human immunodeficiency virus (HIV)-specific immune responses in patients treated during recently acquired hiv infection. J. Infect. Dis. 2002, 185, 61-68. [CrossRef] [PubMed]

26. Chun, T.W.; Engel, D.; Mizell, S.B.; Hallahan, C.W.; Fischette, M.; Park, S.; Davey, R.T., Jr.; Dybul, M.; Kovacs, J.A.; Metcalf, J.A.; et al. Effect of interleukin-2 on the pool of latently infected, resting cd4 ${ }^{+} \mathrm{T}$ cells in hiv-1-infected patients receiving highly active anti-retroviral therapy. Nat. Med. 1999, 5, 651-655. [CrossRef] [PubMed]

27. Nabel, G.; Baltimore, D. An inducible transcription factor activates expression of human immunodeficiency virus in T cells. Nature 1987, 326, 711-713. [CrossRef]

28. Williams, S.A.; Chen, L.F.; Kwon, H.; Fenard, D.; Bisgrove, D.; Verdin, E.; Greene, W.C. Prostratin antagonizes HIV latency by activating nf-kappab. J. Biol. Chem. 2004, 279, 42008-42017. [CrossRef]

29. Korin, Y.D.; Brooks, D.G.; Brown, S.; Korotzer, A.; Zack, J.A. Effects of prostratin on T-cell activation and human immunodeficiency virus latency. J. Virol. 2002, 76, 8118-8123. [CrossRef]

30. Kulkosky, J.; Sullivan, J.; Xu, Y.; Souder, E.; Hamer, D.H.; Pomerantz, R.J. Expression of latent haart-persistent HIV type 1 induced by novel cellular activating agents. AIDS Res. Hum. Retrovir. 2004, 20, 497-505. [CrossRef]

31. Jones, K.A.; Kadonaga, J.T.; Luciw, P.A.; Tjian, R. Activation of the aids retrovirus promoter by the cellular transcription factor, SP1. Science 1986, 232, 755-759. [CrossRef] [PubMed]

32. Perkins, N.D.; Edwards, N.L.; Duckett, C.S.; Agranoff, A.B.; Schmid, R.M.; Nabel, G.J. A cooperative interaction between NF-kappa B and SP1 is required for HIV-1 enhancer activation. EMBO J. 1993, 12, 3551-3558. [CrossRef] [PubMed]

33. El Kharroubi, A.; Piras, G.; Zensen, R.; Martin, M.A. Transcriptional activation of the integrated chromatin-associated human immunodeficiency virus type 1 promoter. Mol. Cell. Biol. 1998, 18, 2535-2544. [CrossRef] [PubMed]

34. Berkhout, B.; Jeang, K.T. Functional roles for the TATA promoter and enhancers in basal and Tat-induced expression of the human immunodeficiency virus type 1 long terminal repeat. J. Virol. 1992, 66, 139-149. 
35. Kaufman, J.D.; Valandra, G.; Roderiquez, G.; Bushar, G.; Giri, C.; Norcross, M.A. Phorbol ester enhances human immunodeficiency virus-promoted gene expression and acts on a repeated 10-base-pair functional enhancer element. Mol. Cell. Biol. 1987, 7, 3759-3766. [CrossRef]

36. Zeichner, S.L.; Kim, J.Y.; Alwine, J.C. Linker-scanning mutational analysis of the transcriptional activity of the human immunodeficiency virus type 1 long terminal repeat. J. Virol. 1991, 65, 2436-2444.

37. Kinoshita, S.; Su, L.; Amano, M.; Timmerman, L.A.; Kaneshima, H.; Nolan, G.P. The t cell activation factor NF-ATC positively regulates HIV-1 replication and gene expression in t cells. Immunity 1997, 6, 235-244. [CrossRef]

38. Tong-Starksen, S.E.; Luciw, P.A.; Peterlin, B.M. Human immunodeficiency virus long terminal repeat responds to T-cell activation signals. Proc. Natl. Acad. Sci. USA 1987, 84, 6845-6849. [CrossRef]

39. Zeichner, S.L.; Hirka, G.; Andrews, P.W.; Alwine, J.C. Differentiation-dependent human immunodeficiency virus long terminal repeat regulatory elements active in human teratocarcinoma cells. J. Virol. 1992, 66, 2268-2273.

40. Marshall, N.F.; Price, D.H. Purification of p-tefb, a transcription factor required for the transition into productive elongation. J. Biol. Chem. 1995, 270, 12335-12338. [CrossRef]

41. Marshall, N.F.; Peng, J.; Xie, Z.; Price, D.H. Control of rna polymerase ii elongation potential by a novel carboxyl-terminal domain kinase. J. Biol. Chem. 1996, 271, 27176-27183. [CrossRef]

42. Yang, X.; Herrmann, C.H.; Rice, A.P. The human immunodeficiency virus tat proteins specifically associate with tak in vivo and require the carboxyl-terminal domain of rna polymerase ii for function. J. Virol. 1996, $70,4576-4584$.

43. Gold, M.O.; Yang, X.; Herrmann, C.H.; Rice, A.P. Pitalre, the catalytic subunit of tak, is required for human immunodeficiency virus tat transactivation in vivo. J. Virol. 1998, 72, 4448-4453.

44. West, M.J.; Lowe, A.D.; Karn, J. Activation of human immunodeficiency virus transcription in T cells revisited: NF-kappaB p65 stimulates transcriptional elongation. J. Virol. 2001, 75, 8524-8537. [CrossRef]

45. Barboric, M.; Nissen, R.M.; Kanazawa, S.; Jabrane-Ferrat, N.; Peterlin, B.M. Nf-kappab binds p-tefb to stimulate transcriptional elongation by rna polymerase II. Mol. Cell 2001, 8, 327-337. [CrossRef]

46. Andersen, J.L.; DeHart, J.L.; Zimmerman, E.S.; Ardon, O.; Kim, B.; Jacquot, G.; Benichou, S.; Planelles, V. Hiv-1 vpr-induced apoptosis is cell cycle dependent and requires bax but not ant. PLoS Pathog. 2006, 2, e127. [CrossRef]

47. Basseres, D.S.; Baldwin, A.S. Nuclear factor-kappab and inhibitor of kappab kinase pathways in oncogenic initiation and progression. Oncogene 2006, 25, 6817-6830. [CrossRef]

48. Ghosh, S.; Hayden, M.S. New regulators of nf-kappab in inflammation. Nat. Rev. Immunol. 2008, 8, 837-848. [CrossRef]

49. Hayden, M.S.; Ghosh, S. Shared principles in NF-kappaB signaling. Cell 2008, 132, 344-362. [CrossRef]

50. Williams, S.A.; Chen, L.F.; Kwon, H.; Ruiz-Jarabo, C.M.; Verdin, E.; Greene, W.C. NF-kappaB p50 promotes hiv latency through hdac recruitment and repression of transcriptional initiation. EMBO J. 2006, 25, 139-149. [CrossRef]

51. Williams, S.A.; Greene, W.C. Regulation of HIV-1 latency by T-cell activation. Cytokine 2007, 39, 63-74. [CrossRef]

52. Geeraert, L.; Kraus, G.; Pomerantz, R.J. Hide-and-seek: The challenge of viral persistence in HIV-1 infection. Annu. Rev. Med. 2008, 59, 487-501. [CrossRef]

53. Hoffmann, A.; Leung, T.H.; Baltimore, D. Genetic analysis of NF-kappaB/rel transcription factors defines functional specificities. EMBO J. 2003, 22, 5530-5539. [CrossRef]

54. Natoli, G.; Saccani, S.; Bosisio, D.; Marazzi, I. Interactions of NF-kappaB with chromatin: The art of being at the right place at the right time. Nat. Immunol. 2005, 6, 439-445. [CrossRef]

55. Hayden, M.S.; Ghosh, S. Signaling to NF-kappaB. Genes Dev. 2004, 18, 2195-2224. [CrossRef]

56. Carmody, R.J.; Ruan, Q.; Palmer, S.; Hilliard, B.; Chen, Y.H. Negative regulation of toll-like receptor signaling by NF-kappaB p50 ubiquitination blockade. Science 2007, 317, 675-678. [CrossRef]

57. Motoyama, M.; Yamazaki, S.; Eto-Kimura, A.; Takeshige, K.; Muta, T. Positive and negative regulation of nuclear factor-kappab-mediated transcription by ikappab-zeta, an inducible nuclear protein. J. Biol. Chem. 2005, 280, 7444-7451. [CrossRef] 
58. Yamamoto, M.; Yamazaki, S.; Uematsu, S.; Sato, S.; Hemmi, H.; Hoshino, K.; Kaisho, T.; Kuwata, H.; Takeuchi, O.; Takeshige, K.; et al. Regulation of toll/IL-1-receptor-mediated gene expression by the inducible nuclear protein ikappabzeta. Nature 2004, 430, 218-222. [CrossRef]

59. Gerondakis, S.; Grumont, R.; Gugasyan, R.; Wong, L.; Isomura, I.; Ho, W.; Banerjee, A. Unravelling the complexities of the nf-kappab signalling pathway using mouse knockout and transgenic models. Oncogene 2006, 25, 6781-6799. [CrossRef]

60. Pasparakis, M.; Luedde, T.; Schmidt-Supprian, M. Dissection of the nf-kappab signalling cascade in transgenic and knockout mice. Cell Death Differ. 2006, 13, 861-872. [CrossRef]

61. Klement, J.F.; Rice, N.R.; Car, B.D.; Abbondanzo, S.J.; Powers, G.D.; Bhatt, P.H.; Chen, C.H.; Rosen, C.A.; Stewart, C.L. Ikappabalpha deficiency results in a sustained nf-kappab response and severe widespread dermatitis in mice. Mol. Cell. Biol. 1996, 16, 2341-2349. [CrossRef] [PubMed]

62. Thompson, J.E.; Phillips, R.J.; Erdjument-Bromage, H.; Tempst, P.; Ghosh, S. I kappa B-beta regulates the persistent response in a biphasic activation of NF-kappa B. Cell 1995, 80, 573-582. [CrossRef]

63. Griffin, B.D.; Moynagh, P.N. In vivo binding of nf-kappab to the ikappabbeta promoter is insufficient for transcriptional activation. Biochem. J. 2006, 400, 115-125. [CrossRef] [PubMed]

64. Whiteside, S.T.; Epinat, J.C.; Rice, N.R.; Israel, A. I kappa b epsilon, a novel member of the I kappa B family, controls rela and crel nf-kappa b activity. EMBO J. 1997, 16, 1413-1426. [CrossRef] [PubMed]

65. Li, Z.; Nabel, G.J. A new member of the i kappab protein family, i kappab epsilon, inhibits rela (p65)-mediated nf-kappab transcription. Mol. Cell. Biol. 1997, 17, 6184-6190. [CrossRef]

66. Memet, S.; Laouini, D.; Epinat, J.C.; Whiteside, S.T.; Goudeau, B.; Philpott, D.; Kayal, S.; Sansonetti, P.J.; Berche, P.; Kanellopoulos, J.; et al. Ikappabepsilon-deficient mice: Reduction of one T cell precursor subspecies and enhanced ig isotype switching and cytokine synthesis. J. Immunol. 1999, 163, 5994-6005.

67. Fernandez, G.; Zaikos, T.D.; Khan, S.Z.; Jacobi, A.M.; Behlke, M.A.; Zeichner, S.L. Targeting ikappab proteins for HIV latency activation: The role of individual ikappab and nf-kappab proteins. J. Virol. 2013, 87, 3966-3978. [CrossRef]

68. Folks, T.M.; Justement, J.; Kinter, A.; Dinarello, C.A.; Fauci, A.S. Cytokine-induced expression of HIV-1 in a chronically infected promonocyte cell line. Science 1987, 238, 800-802. [CrossRef]

69. Perez, V.L.; Rowe, T.; Justement, J.S.; Butera, S.T.; June, C.H.; Folks, T.M. An HIV-1-infected T cell clone defective in IL-2 production and Ca2+ mobilization after CD3 stimulation. J. Immunol. 1991, 147, 3145-3148.

70. Clouse, K.A.; Powell, D.; Washington, I.; Poli, G.; Strebel, K.; Farrar, W.; Barstad, P.; Kovacs, J.; Fauci, A.S.; Folks, T.M. Monokine regulation of human immunodeficiency virus-1 expression in a chronically infected human T cell clone. J. Immunol. 1989, 142, 431-438.

71. Folks, T.M.; Clouse, K.A.; Justement, J.; Rabson, A.; Duh, E.; Kehrl, J.H.; Fauci, A.S. Tumor necrosis factor alpha induces expression of human immunodeficiency virus in a chronically infected T-cell clone. Proc. Natl. Acad. Sci. USA 1989, 86, 2365-2368. [CrossRef] [PubMed]

72. Fernandez, G.; Zaikos, T.D.; Khan, S.Z.; Jacobi, A.; Behlke, M.; Zeichner, S.L. Targeting ikb proteins for hiv latency activation: The role of individual ikb and nf-kb proteins. J. Virol. 2019, in press.

73. Human Microbiome Project, C. Structure, function and diversity of the healthy human microbiome. Nature 2012, 486, 207-214. [CrossRef] [PubMed]

74. Gilmore, T.D. Introduction to nf-kappab: Players, pathways, perspectives. Oncogene 2006, 25, 6680-6684. [CrossRef] [PubMed]

75. Emiliani, S.; Fischle, W.; Ott, M.; Van Lint, C.; Amella, C.A.; Verdin, E. Mutations in the tat gene are responsible for human immunodeficiency virus type 1 postintegration latency in the u1 cell line. J. Virol. 1998, 72, 1666-1670. [PubMed]

76. Emiliani, S.; Van Lint, C.; Fischle, W.; Paras, P., Jr.; Ott, M.; Brady, J.; Verdin, E. A point mutation in the hiv-1 tat responsive element is associated with postintegration latency. Proc. Natl. Acad. Sci. USA 1996, 93, 6377-6381. [CrossRef] 
77. Gilmore, T.D.; Gerondakis, S. The c-rel transcription factor in development and disease. Genes Cancer 2011, 2, 695-711. [CrossRef]

78. Schwartz, C.; Bouchat, S.; Marban, C.; Gautier, V.; Van Lint, C.; Rohr, O.; Le Douce, V. On the way to find a cure: Purging latent HIV-1 reservoirs. Biochem. Pharmacol. 2017, 146, 10-22. [CrossRef] 